This work is licensed under a Creative Commons Attribution 4.0 International License.

Ovaj rad dostupan je za upotrebu pod međunarodnom licencom Creative Commons Attribution 4.0.

\title{
Sabira Hajdarević
}

\section{„VODENA” EROTSKA METAFORIKA U GRČKIM FIKCIONALNIM EPISTOLARNIM ZBIRKAMA}

dr. sc. Sabira Hajdarević, Sveučilište u Zadru, shajdarevic@unizd.hr, Zadar

izvorni znanstveni članak

UDK 821.14.09-6

rukopis primljen 16. 2. 2018; prihvaćen za tisak: 15. 11. 2018.

\begin{abstract}
U radu se istražuje zastupljenost i način upotrebe „vodenih” slikovitih izraza (metafora, metonimija, eufemizama itd.) koji su u službi opisa erotike u Alkifronovoj, Filostratovoj i Aristenetovoj fikcionalnoj epistolarnoj zbirci. Analiziran je dijapazon njihovih značenja u pismima (zaljubljenost $i$ želja, zavođenje, predigra ili seksualni čin), a dobiveni pojedinačni rezultati stavljeni su u širi kontekst; primjeri su kvantitativno i kvalitativno međusobno uspoređeni, tj. promotren je omjer njihove zastupljenosti i važnosti od zbirke do zbirke. S obzirom na podudarnost tema, zanimanja korespondenata $i$ mjesta radnje u zbirkama, očekivana je znatna sličnost i srodnost korištenih stilskih sredstava, njihova porijekla te načina upotrebe. Konačni je cilj definiranje karakteristika odabira i načina korištenja „vodenih” erotskih izraza koje možemo smatrati generičkima, kao i izdvajanje eventualnih individualnih doprinosa (tj. inovacija) svakoga od autora.
\end{abstract}

Ključne riječi: grčka fikcionalna epistolografija; Alkifron; Filostrat; Aristenet; erotska metaforika; erotski izrazi

\section{Uvod}

Epistolarna komunikacija dugo je antičkim Grcima bila relativno strana; pismenost nije bila općeprisutna pojava, a poštanski sustav nije postojao. Tek krajem 5. i kroz 4. st. pr. n. e. pisanje i slanje pisama postaje uobičajenije 
(Rosenmeyer 2001: 19-22), a otad pratimo i tzv. umetnuta pisma. ${ }^{1}$ Međutim, samostalna književna djela u potpunosti sastavljena od fikcionalnih pisama, tj. epistolarne zbirke, pronalazimo tek mnogo kasnije, od 2. stoljeća n. e. Do nas ih je došlo samo pet: Alkifronova, Elijanova i Filostratova (sve iz 2. ili 3. st.), Aristenetova (5. ili 6. st.) te Teofilaktova (7. st.). U zbirkama prevladava erotska tematika. Oko njihova vremena i mjesta nastanka postoji mnoštvo nepoznanica, a biografski podaci o autorima vrlo su nepouzdani.

Konvencije grčke fikcionalne epistolografije zabranjuju opscenosti pri opisivanju seksualne želje ili njezina ispunjenja. ${ }^{2}$ Ta činjenica dijelom je rezultat porijekla podvrste; razvila se postupno iz prakse upotrebe pisama kao retoričkih vježbi u školama. Budući da zbirke ove vrste susrećemo tijekom perioda Druge sofistike i nakon nje, ${ }^{3}$ ne smijemo isključiti utjecaj novih književnih strujanja na njihove sadržajne i formalne karakteristike (Hajdarević 2015: 20-24), a možda su i moralni stavovi autora utjecali na podvrstu i učinili je pristojnom (usp. Arnott 1982: 312). Ipak, opisi golotinje i aluzije na fizičke kontakte nisu mogli sasvim izostati nakon što je odabrana erotska tematika. ${ }^{4}$ Dakle, autori su u pismima morali izbjeći nedoličnost direktnog izraza, ali istovremeno i zagolicati maštu čitatelja te im barem minimalno zadovoljiti radoznalost. Posljedično, stilska sredstva kojima su stvarane erotske aluzije morala su biti mnogobrojna, šarolika te raznovrsna porijeklom, a moć metafora, metonimija i eufemističkih izraza došla je u zbirkama ove vrste u prvi plan (Hajdarević 2017b: 4).

\subsection{Definiranje cilja i metodologije istraživanja}

Raznovrsnost slikovitih erotskih izraza i njihova važnost za prikaz golotinje i fizičkih kontakata potaknuli su na ideju njihove detaljnije analize te naknadne usporedbe stanja u zbirkama; ovo istraživanje dijelom je nasta-

1 Umetnuta pisma (embedded letters) pronalazimo u Euripidovim tragedijama ( $\mathrm{u}$ nekolicini izgubljenih te u Ifigenijama i Hipolitu), historiografiji (Herodot, Tukidid, Ksenofont itd.), Novoj komediji i romanima. S vremenom postaju sve važnija za pokretanje radnje (tzv. kinetička pisma) i oblikovanje zapleta ili raspleta.

$2 \mathrm{Na}$ ovom mjestu smatram potrebnim naglasiti da velik dio književne produkcije Grka karakterizira poprilična pristojnost. Iznimke su Stara komedija, Lukijanovi dijalozi i dio epigrama, ali ne postoji npr. pandan Marcijalu.

3 O Drugoj sofistici kao kulturnom pokretu usp. detaljnije u Anderson 1993.

4 U slučaju Filostratove zbirke erotska tematika najavljena je i naslovom; leksikon Suda

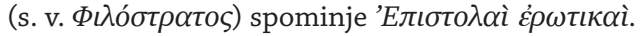


vak i produbljenje ranijih spoznaja (usp. Hodkinson 2009, Hajdarević 2013: 218-236, 258 i 262, 2017a te 2017b: 6-26). Početni korak je detaljno iščitavanje teksta pisama, sveobuhvatna analiza erotskog vokabulara te izdvajanje svih erotskih metafora, metonimija, eufemizama, aluzija itd. u epistolarnim zbirkama koje uzimam u obzir. ${ }^{5}$ Sukladno brojnosti detektiranih primjera, za potrebe ovog rada fokus analize morao je biti sužen; odabrani su izrazi u kojima je uočena konceptualizacija ljubavnih i erotskih odnosa koji se razumijevaju s pomoću pojma „voda”. Dakle, riječ je o konceptualnim metaforama i metonimijama u kojima su erotski odnosi (tj. ciljna domena) opisani putem sljedećih izraza vezanih uz vodu (izvorna domena): ${ }^{6}$ voda kao prirodna sila ili sredstvo za gašenje požara, konzumacija vode ili osjet žeđi, plovidba i ribolov. U nastavku je analiziran dijapazon značenja koja takvi izrazi poprimaju (zaljubljenost, zavođenje, predigra ili seksualni čin) te im je provjeren kontekst pojavljivanja u domicilnom pismu (npr. odvija li se radnja uz vodu, jesu li korespondenti ribari ili pomorci i sl.). ${ }^{7}$ Pojedinačni rezultati stavljeni su u širi kontekst; primjeri su kvantitativno i kvalitativno međusobno uspoređeni, tj. promotren je omjer njihove zastupljenosti i važnosti od zbirke do zbirke. S obzirom na podudarnost tema, zanimanja korespondenata i mjesta radnje u zbirkama,

5 Analizirane su Alkifronova, Filostratova i Aristenetova zbirka. Elijanova je isključena jer je ukupan broj pisama u njoj zanemarivo malen (svega 20, a od njih samo pet ima erotsku tematiku) i jer osvrti znanstvenika redom naglašavaju autorovu neinventivnost te ogroman Alkifronov utjecaj (Benner i Fobes 1949: 344). Preostala, Teofilaktova, pripada već bizantskoj književnosti. Analiza je odrađena na grčkim tekstovima uz pomoć postojećih prijevoda na engleski jezik; nijedna od zbirki dosad nije prevedena na hrvatski.

6 „Konceptualna je metafora jedan od kognitivnih procesa konstruiranja značenja na temelju kojeg povezujemo dvije konceptualne domene: izvornu domenu (engl. source domain) i ciljnu domenu (engl. target domain)" (Stanojević 2009: 340).

7 U Alkifronovoj zbirci gotovo petinu pisama pišu ribari, kao i poneka pisma u Aristenetovoj. Očekujem bar nešto veću učestalost konceptualnih metafora iz sfere vode u pismima ljudi čije zanimanje podrazumijeva dugotrajne aktivnosti vezane uz vodu, plovidbu i ribolov, relativno malo kontakata s pripadnicima drugih profesija te nisku razinu općeg obrazovanja. Naime, „konceptualna se motiviranost metafora i metonimija odnosi na njihovo iskustveno utemeljenje” (Stanojević 2009: 344), a „činjenica da su konceptualne metafore motivirane znači da su nam neke od njih iskustveno bliže, pa ih samim time češće i lakše rabimo i razumijemo" (Stanojević 2009: 345). Naravno, to nipošto ne znači da cjelokupna metaforika ribara nužno potječe jedino iz sfere vode, niti da pripadnici drugih zanimanja metaforiku ove vrste ne koriste; kad nastane razmjerno stabilna te učestalo (i u jeziku i u književnim djelima) korištena veza između izvorne i ciljne domene, konceptualne metafore mogu postati stalne i uobičajene, odnosno konvencionalizirane (usp. Stanojević 2013: 55 i 93). 
očekivana je znatna sličnost i srodnost korištenih stilskih sredstava, njihova porijekla i načina upotrebe.

Konačni je cilj definiranje karakteristika odabira i načina korištenja „Vodenih” erotskih izraza koje možemo smatrati generičkima, kao i izdvajanje eventualnih izoliranih obilježja koja predstavljaju individualne doprinose (tj. inovacije) svakoga od autora. ${ }^{8}$

Prije prikaza interpretacije primjera i njihovih značenjskih domena, zbirke koje će biti predmetom istraživanja predstavit će se u kratkim crtama.

\subsection{Fikcionalne epistolarne zbirke i njihovi autori}

Alkifron je živio između 170. i 220. godine (Benner i Fobes 1949: 18). Njegova zbirka najopsežnija je od sačuvanih; broji 123 pisma koja su razdijeljena u četiri cjeline, naslovljene sukladno zanimanjima aktera: Pisma ribara, Pisma seljaka, Pisma parazita i Pisma hetera. Pisma su rijetko odgovorena ili međusobno temama povezana, ${ }^{9}$ a prikazuju grčki svijet 4 . stoljeća pr. n. e. Editio princeps zbirke priredio je Musurus 1499. godine u Veneciji (Apud Aldum), skupa s Elijanovom, Filostratovom i Teofilaktovom (pod

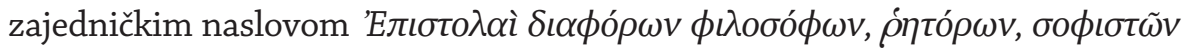

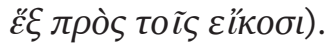

Flavije Filostrat II vjerojatni je autor zbirke sastavljene od 73 pisma. Riječ je o sofistu porijeklom s otoka Lemna koji je živio u Rimu na prijelazu iz 2. u 3. stoljeće i kretao se u uskom krugu intelektualaca okupljenih oko Septimija Severa i njegove supruge, Julije Domne (Anderson 1986: 274-275). Sam autor pošiljatelj je svih pisama, a primatelji su uglavnom neimenovani. Prednjače erotska pisma (takvih je 50-ak), a ostala su kratki aforizmi (npr. 65), pisma pohvale i osvrti o kulturnim strujanjima (73). U erotskim pismima autor zavodi podjednako muškarce i žene; ovo je jedina sačuvana fikcionalna zbirka u kojoj pronalazimo i homoseksualne sklonosti.

8 Zbog ograničenog opsega rada ne namjeravam utvrđivati razinu originalnosti izdvojenih izraza niti ukazivati na brojne paralele s tuđim ulomcima. Naime, intertekstualnost je jedna od bitnih odrednica grčke fikcionalne epistolografije kao podvrste i dobar dio analiziranih primjera vjerojatno je preuzet ili bar stvoren po uzoru na ulomke ranijih grčkih, ali i ponekih rimskih autora (npr. Alkej, Sapfa, Euripid, Platon, Kalimah, Lukijan, Katul, Horacije, Ovidije itd.). Također, nužno je pretpostaviti i da je dio promatranih izraza pripadao općem jeziku, a ne nužno (samo) ranijim književnim djelima.

9 Tematske poveznice i učestala ponavljanja korespondenata postoje samo u 4 . knjizi. 
Aristenetova zbirka nastala je između 490. i 520 godine (Drago 2007: 25-36), a sastoji se od 50 pisama erotske tematike, podijeljenih u dvije knjige. Autorstvo je problematično; neki smatraju da je ime Aristenet samo pseudonim, tj. da je prepisano iz titula prvoga pisma (tako se zove pošiljatelj) nakon što se folij s pravim imenom autora izgubio, možda skupa s krajem pisma 2.22 i eventualno nekim dodatnima (Arnott 1982: 293-294), dok drugi umetanje vlastitog imena među korespondente ne smatraju neobičnim jer su među njima i drugi epistolografi: Alkifron, Elijan i Filostrat (v. Zanetto 1987: 197). Editio princeps priredio je Sambucus, a izdan je 1566. u

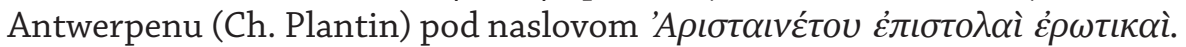

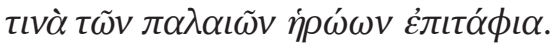

\section{2. „Vodeni” erotski izrazi}

Nakon detaljne analize zbirki i izdvajanja svih erotskih izraza, podijeljeni su prema kriteriju semantičkog porijekla u ukupno 10 kategorija, tj. sfera: sfera užitka, pogreške, nasilja, vatre, vode, pokušaja, sjedinjenja, upotrebe, različitih zanimanja te nesvrstani primjeri. ${ }^{10}$ Ukupan broj primjera $\mathrm{u}$ Alkifronovoj zbirci je 153, u Filostratovoj 112, a u Aristenetovoj čak 282. Ukoliko promatramo samo konceptualne metafore i metonimije koje svoj leksički materijal crpe iz izvorne domene „voda”, u Alkifronovoj zbirci ih uočavamo 7, u Filostratovoj 6, a u Aristenetovoj 19. U nastavku slijedi njihova analiza $\mathrm{i}$ interpretacija. ${ }^{11}$

\subsection{Alkifronova zbirka}

Detektirano je samo 7 primjera u pismima ove zbirke. Percepcija strasti

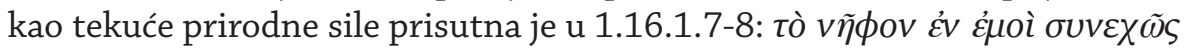

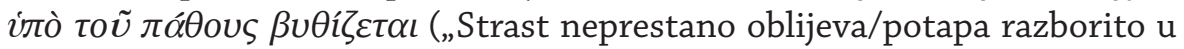
meni"); oblivenost aludira na nemoć zaljubljenog muškarca. U istom pismu (1.16.1.6-7) strast i zaljubljenost, personificirane u Erosa, ometaju ispravan

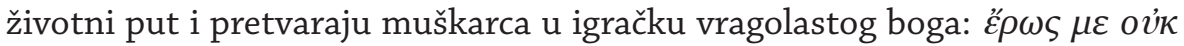

10 Metodologija i kategorizacija većim dijelom se podudaraju s onima iz sličnog istraživanja provedenog nad Alkifronovom zbirkom (v. Hajdarević 2017a i b), ali je sfera vode ovdje shvaćena drugačije. Naime, voda i njezina konzumacija odvojene su od botanike i konzumacije hrane (u prethodnim radovima: kategorija $\mathrm{V}$ ), a dodani su pojedini primjeri koji su tamo bili izdvojeni u kategoriju zanimanja (neke ribolovne metafore) i među neriješene slučajeve (par metonimija).

11 Za Alkifronova i Filostratova pisma koristim izdanje Bennera i Fobesa iz 1949. godine, a za Aristenetova Mazalovo iz 1971. Svi prijevodi citata u radu su moji. 


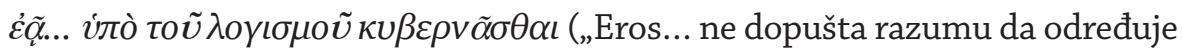
moj kurs"). Dakle, ljubav je smetnja u plovidbi, tj. životna komplikacija. Najzanimljiviji primjer zbirke je neobična personifikacija ljubavi, tj. neoče-

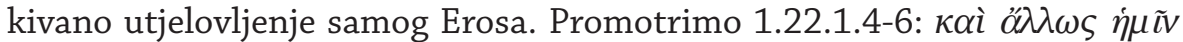

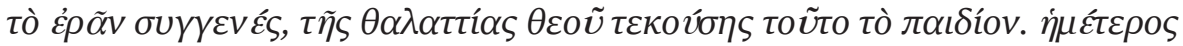

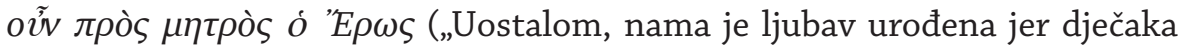
(sc. Erosa) je rodila boginja iz mora. Dakle, s majčine strane Eros je jedan od nas!"). Neobičnom logikom ribara-pošiljatelja, sam bog Eros postao je pripadnik ribarskog zanata!

U 1.21.3.2-5 pošiljatelj pisma dobronamjerno upozorava prijatelja na

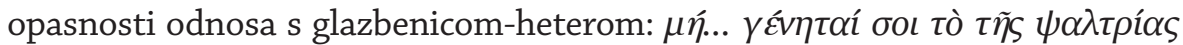

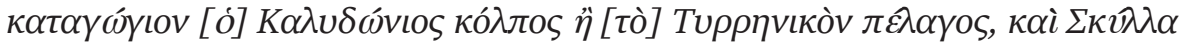

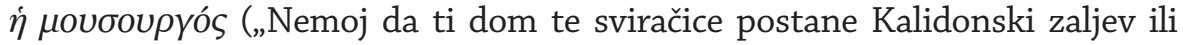
Tirensko more, a glazbenica Skila!"). Očito, zaljubljenost muškarca dovodi ga na emocionalnom planu u jednaku opasnost u kakvoj bi bio da u profesionalnom djelovanju odluta u krajeve koji su slovili kao opasni za plovidbu. Nadalje, metaforička slika Skile stvara dojam objektifikacije muškarca; Skila je Alkifronovim čitateljima dobro poznata kao čudovište koje proždire mornare u Homerovoj Odiseji, a protagonist ovog pisma je upozoren je da bi, poput njih, mogao postati nemoćnom žrtvom drugog čudovišta - pohlepne (ujedno i razvratne) glazbenice. Postojala je dvojba oko preciznog definiranja značenjske kategorije; aludira se na svojevrsnu ljubavnu vezu sa spomenutom ženom, ali i na fizičke odnose s njom. Ipak, spomen njezina doma smatram konkretnom metonimijom za seksualne odnose koji se u njemu odvijaju. Slična je situacija i s dva preostala primjera; u oba je riječ o dugotrajnijoj aferi i iz konteksta je očito da je muškarac zaljubljen, ali zbog činjenice da je prikazan odnos s heterom smatram da je naglasak na seksualnim odnosima. Promotrimo: muškarca-preljubnika u 1.6.2.2 supruga optužuje da je „obliven

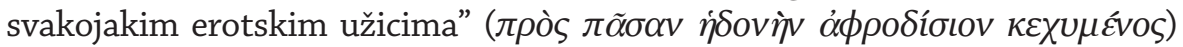
te da njegova ljubavnica (hetera) "guta poput Haribde” (v. óv $\alpha \lambda o \tilde{\imath} X \alpha \rho u ́ \beta \delta \varepsilon \omega \varsigma$

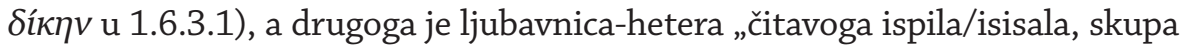

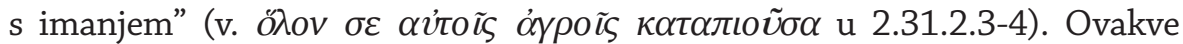
konzumativne metafore i poredbe karakteristične su za opise odnosa $\mathrm{s}$ heterama u Alkifronovoj zbirci (aludiraju istovremeno na pohlepu i na seksualnu nezasitnost). ${ }^{12}$

12 Hetere su u grčkoj književnosti u cjelini redovito uspoređivane s divljim zvijerima (često lavicama) ili s opasnim i proždrljivim čudovištima. Prikazom se aludira na njihovu pohlepu 


\subsection{Filostratova zbirka}

I Filostratova zbirka relativno je siromašna primjerima; izdvojeno ih je svega 6. Zaljubljenost je u 50, 8-9 opisana pomorskim vokabularom: želja je tekućeg oblika, a uz to predstavlja i opasnost od potencijalnog utapanja: $\delta$

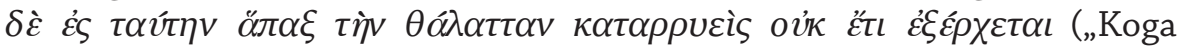
jednom oblije ovo more, taj više ne izranja."). Očekivano, vizualna percepcija osobe (muške ili ženske) učestalo uzrokuje želju i emocije u pismima, a detektiran je primjer u kojemu je uzročnik budućih nevolja (ljepota)

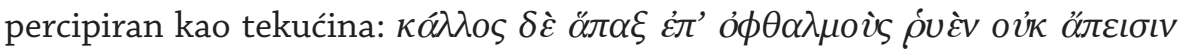
(v. „A ljepota, nakon što se jednom ulila u oči, ne odlazi” u 10.5-6). Osjet žeđi može aludirati na frustraciju zbog neutažene seksualne želje, kao u

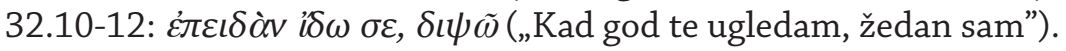

Sukladno asocijaciji žeđ: seksualna želja, spomenom konzumacije

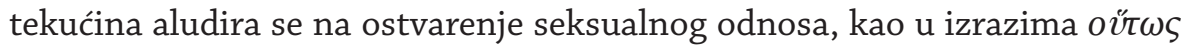

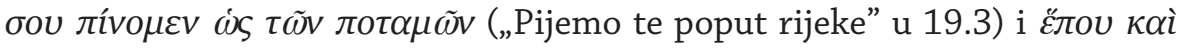

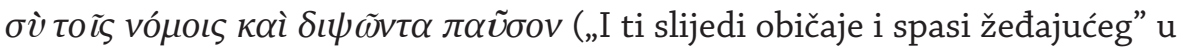
26.7).

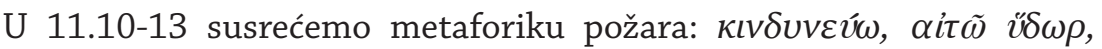

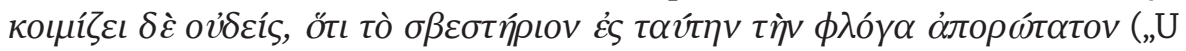
nevolji/opasnosti sam, tražim vodu, ali nitko je ne donosi jer sredstvo za gašenje ove vatre teško se pronalazi”). Jasno, požar aludira na seksualnu želju, dok je „sredstvo za gašenje” metafora za seksualni čin.

\subsection{Aristenetova zbirka}

Ukupno je 19 erotskih izraza, a većina ih aludira na seksualnu želju ili zaljubljenost (njih 10). Pritom je sama želja uobičajeno percipirana kao

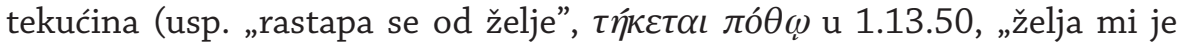

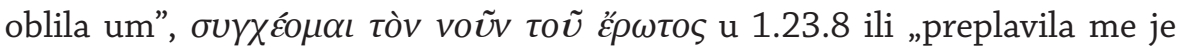

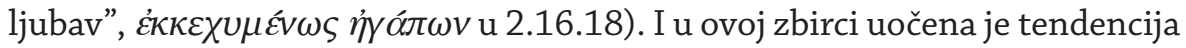
povezivanja stanja oblivenosti i potencijalne opasnosti od utapanja, kao npr. u alegorijskoj paraleli zaljubljeni muškarac: brod u oluji (v. „Nastavi ti pjevati i bdjeti bez ikakvog učinka, bacan unaokolo valovima strasti”,

za zaradom te činjenicu da su jedine od grčkih žena mogle birati ljubavnike, odbijati ih ili držati u vlastitoj moći vještim taktikama zavođenja i tako ugrožavati njihove brakove (na financijskim, ali često i emocionalnim poljima). O vokabularu nasilja, ropstva i konzumacije povezanim uz njih u grčkoj fikcionalnoj epistolografiji usp. detaljnije u Hajdarević 2017a i b. 


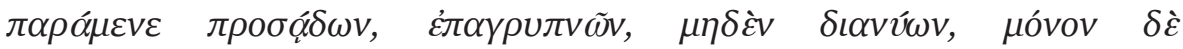

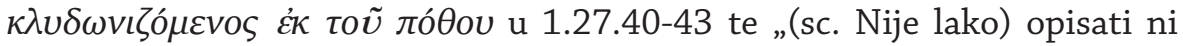

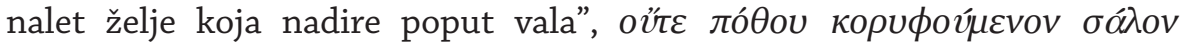
$\varepsilon \dot{u} \mu \alpha \rho \grave{\varepsilon} \varsigma \dot{\alpha} \phi \eta \gamma \varepsilon \tilde{\imath} \sigma \theta \alpha \iota$ u $1.10 .47-48) .{ }^{13}$ Zanimljiv je primjer u kojemu je zaljubljeni muškarac kormilar broda zahvaćenog olujom na pučini; želja je, kao u prethodnim primjerima, dovela do opasnosti od brodoloma, a njegova istodobna zaljubljenost u dvije žene, suprugu i ljubavnicu, prikazana je slikom sukoba suprotstavljenih vjetrova koji podižu valove („Nalik sam kormilaru kojeg napadaju dva vjetra svaki sa svoje strane i bore se za lađu",

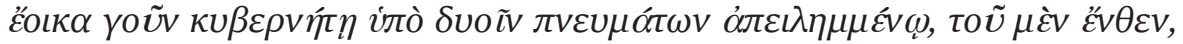

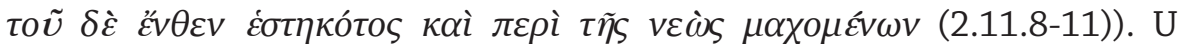
2.18.6-7 ljepota, percipirana kao tekućina, kauzativ je zaljubljenja;

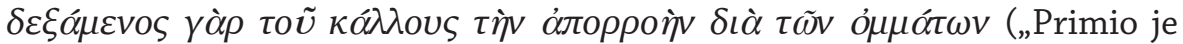
riječni tok ljepote očima”). Lađa u 1.17.31-32 predstavlja zaljubljenost, ali i seksualnu zanemarenost; ženina ćud je ta koja određuje kurs, tj. smjer veze i seksualno (ne)ispunjenje - usp. „Zajednička lađa, zajednička i nevolja”,

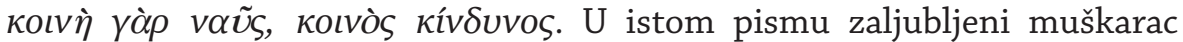
uspoređen je s valom: $\kappa \alpha \grave{\imath} \sigma \grave{v} \gamma \grave{\alpha} \rho$ ó

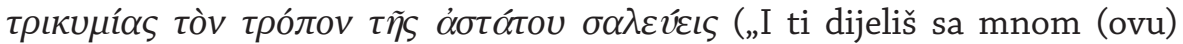
strast i kolebaš se poput nestalnog (uzburkanog) vala" u 1.17.29-31). Osjećaj žeđi, spomenut u 2.10.14-15, jasna je aluzija na seksualnu frustraciju:

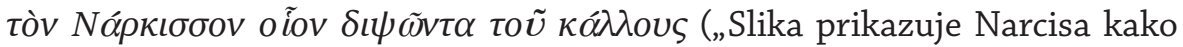
žeđa za svojom ljepotom").

Nekolicini primjera kojima se opisuje zavođenje ili zavodljivost zajednička je poveznica s ribolovnim aktivnostima. Interesantnom usporedbom u 2.21.16-18 ženina neodoljivost izjednačena je sa silom kojom ribar na

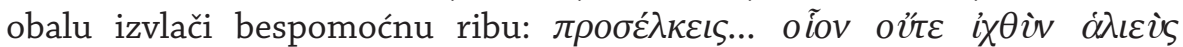

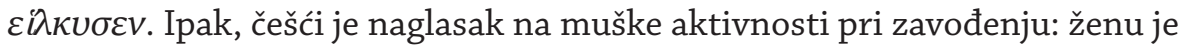

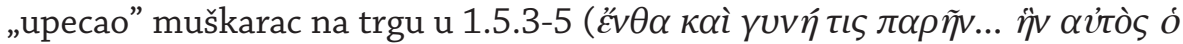

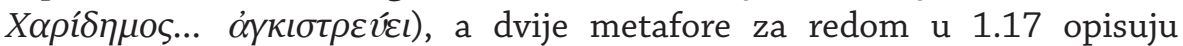
strpljivost ribolovca, tj. upornost kao nenadmašnu taktiku zavođenja (usp. „Ako proguta udicu, ponovo ću je zabaciti, a treći put ću povući oštricu

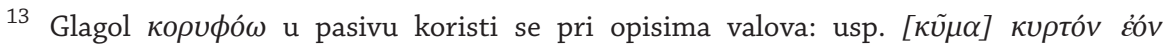

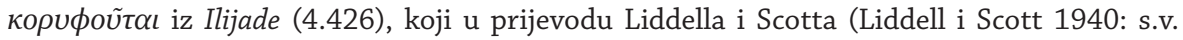
$\kappa o \rho v \phi o ́ \omega)$ glasi rises with arching crest. Kalimah u Aetia 110.6 ima izraz vrlo sličan Aristenetovom, a kod Katula nalazimo tantis fluctuat ipsa malis u 65. 4 (usp. Hunter 2009: 209). 


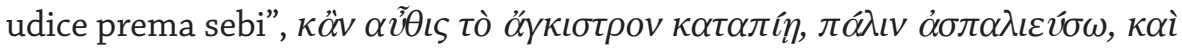

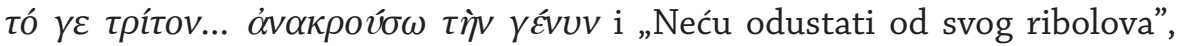

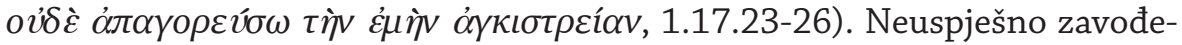
nje Aristenet prikazuje maštovitom plovidbenom metaforom u 2.17.10-11

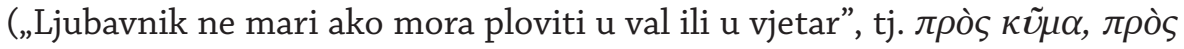

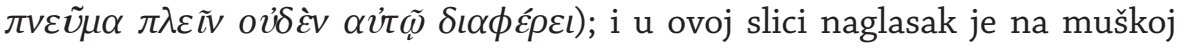
upornosti. Najzanimljiviji primjer zbirke nažalost nije autorova originalna

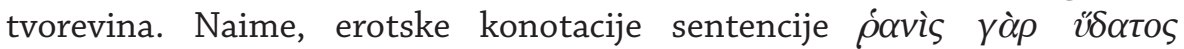

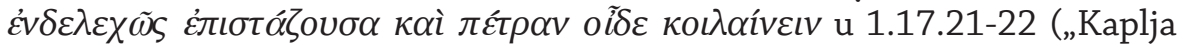
vode koja učestalo pada zna i stijenu izdupsti") vjerojatno su preuzete od Ovidija (usp. Ars Amatoria 1.476). Pritom prvi dio metaforičke slike (opet) aludira na upornost kao najefikasniju metodu zavođenja, dok drugi anticipira cilj - seksualni odnos (iz tog razloga primjer će biti izdvojen dvaput, v. niže).

Sukladno učestalosti paralele ribarenje: zavođenje, ne iznenađuje da je metaforički ribolovni neuspjeh jednak izostanku seksualnog odnosa.

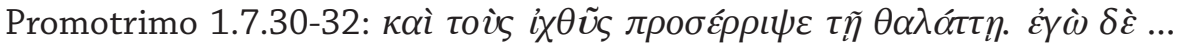

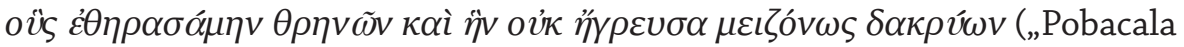
mi je ribe u more, a ja sam kukao za ulovom koji sam ulovio, a još više za njom, koju nisam uhvatio"). Relativno očekivanu poveznicu vatra: voda (u smislu odnosa strasti i njezina utaženja seksom) pronalazimo, začudo,

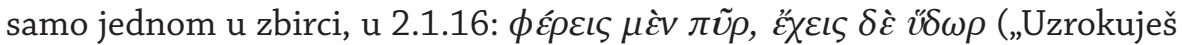
vatru, ali posjeduješ i vodu"). Drugi dio sentencije koju smo već susreli,

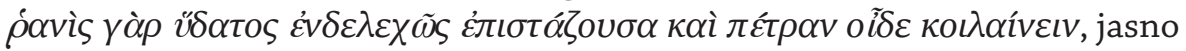
aludira na seksualni odnos kao „nagradu” za upornost.

\section{Interpretacija rezultata}

Dobivene podatke potrebno je staviti u širi kontekst, unatoč svim poteškoćama koje donosi interpretacija i statistička obrada relativno malog uzorka.

\subsection{Alkifronova zbirka}

U Alkifronovoj zbirci detektirano je samo 7 erotskih izraza s izvornom domenom „voda”, što iznenađuje: zbirka je najopsežnija od promatranih (ima 123 pisma), stoga je u njoj bio očekivan veći broj slikovitih izraza općenito, tako i „vodenih”. Osim toga, otprilike četvrtinu pisama pišu i šalju ribari, a pretpostavka je bila da su u njihovom vokabularu relativno 
česti izrazi iz sfere vode. ${ }^{14}$ Dio objašnjenja ovakve oskudice leži u činjenici da je od ukupnog broja pisama zbirke samo njih 25 erotske tematike (20 iz Pisama hetera te još ukupno svega pet iz knjiga 1-3).

Dakle, postotak zastupljenosti izraza ove vrste je poprilično malen, oko 4.5\%; kudikamo su učestaliji oni iz sfera (redom) upotrebe, nasilja, pogreške, veselja i pokušaja. Primjeri su značenjski prilično ravnomjerno raspoređeni: tri aludiraju na želju i zaljubljenost, a četiri na seksualni odnos. Želja je percipirana kao tekućina, zaljubljenost kao potencijal za katastrofu (plovidba u oluji, mogući brodolom), a poveznica i s tekućinom i s opasnošću zadržana je i kad akteri „vodenim” izrazima aludiraju na seks.

Zanimljivo, baš sve primjere u kojima je ovovrsna metaforika iskorištena pronalazimo u pismima koja portretiraju odnose s heterama. U toj činjenici vidim dio odgovora direktne poveznice zaljubljenosti muškarca ili ostvarene veze s opasnošću: hetere su u literaturi Grka uobičajeno portretirane vokabularom nadmoći, robovlasništva, čak i nasilja nad muškarcimažrtvama (usp. Hajdarević 2017a), nezasitne su i predstavljaju potencijal za propast (a s financijske strane ta opasnost je donekle i realna). Također, svi primjeri mogućeg utapanja ili postajanja žrtvom (morskom) čudovištu upozorenja su osoba sa strane, a motivacija su im dobronamjerno prijateljstvo (npr. 1.16 piše ribar svom zaljubljenom kolegi) ili ugroženost vlastitog položaja (1.6 i 2.31 pišu prevarene supruge). Sukladno rečenome, „Vodene” erotske izraze uopće ne pronalazimo u vokabularu hetera.

Šest primjera potječe iz Pisama ribara. Ovakva kontekstualna „predvidljivost" ne iznenađuje i u skladu je s početnim pretpostavkama: Alkifronovi ribari, po čitav dan okruženi tekućinom koja im život znači, i pri slikovitom izražavanju rado koriste vokabular inspiriran onime što im je dobro poznato i "domaće", a to su plovidba, more i oluje na njemu. ${ }^{15}$ Preostali primjer

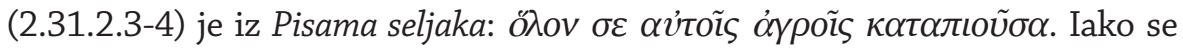
oblicima glagola $\kappa \alpha \tau \alpha \pi i v \omega$ u pojedinim kontekstima može aludirati i na gutanje krutih tvari, a ne nužno tekućina (v. Liddell i Scott 1940: s.v. $\kappa \alpha \tau \alpha \pi i ́ v \omega)$, primjer je nužno uzeti u obzir jer etimološka veza s лìv $\omega$ postoji i dalje; riječ je o „okamenjenoj” metafori i konvencionalnoj kolokaciji uz tò

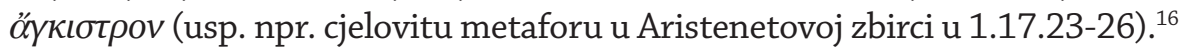

\footnotetext{
14 Usp. fusnotu 7.

15 Slično vrijedi i za izražavanje njihovih supruga i kćeri.

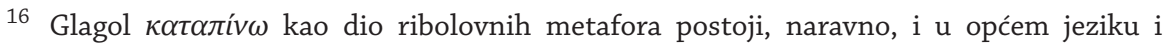
djelima mnoštva antičkih autora koji su vjerojatno na trojicu promatranih autora utjecali
} 


\subsection{Filostratova zbirka}

Svega 5.5\% Filostratovih slikovitih izraza sadrži poveznicu s vodom; u erotskom vokabularu njegovih protagonista kudikamo učestalije su npr. metaforika vatre, nasilja i sjedinjenja. Tekućina je u tri primjera povezana sa seksualnom željom: „ljepota se ulijeva” i uzrokuje ju, jedan zaljubljeni muškarac je potencijalni utopljenik, a drugi žeđa. Sukladno zadnjem primjeru, pijenje je dvaput metafora za ostvarenje odnosa, a u 11, 10-13 utaženje žeđi opisano je vatrogasnom metaforikom umjesto konzumativne.

U zbirci nema preciziranja mjesta radnje niti zanimanja primatelja; ${ }^{17}$ nema govora o ribarima i njihovim životima, stoga ne možemo istraživati ni eventualnu uvjetovanost pojave Filostratove „vodene” metaforike.

\subsection{Aristenetova zbirka}

Izrazi s vodenim konotacijama sudjeluju postotkom od oko 7\%. Više od polovine primjera prikazuje želju ili zaljubljenost: ljepota je i u ovoj zbirci percipirana kao likvidni kauzativ zaljubljenosti, a sama želja triput kao tekućina. Poveznica zaljubljenosti i opasnosti na moru prisutna je u četiri primjera, a želja kao osjet žeđi jednom. Zanimljiva je personifikacija zaljubljeni muškarac $=$ val na milosti i nemilosti vjetrovima.

Bitna novost je autorov fokus na opise zavodljivosti i procesa zavođenja (čak 6 primjera). Pritom je ribolovna metaforika jednom iskorištena za opis ženske privlačnosti, a triput za prikaz muškog zavođenja. Neuspjelo zavođenje autor je prikazao kao plovidbu uz vjetar i ususret valovima, a upornost kao taktiku Ovidijevom slikom kapanja vode na kamen.

Na seks se aludira samo triput: predočen je slikom (ne)uspjela ribolova, vatrogasnom paralelom te (već spomenutom) metaforom u kojoj mnoštvo kapi (uporno zavođenje) rezultira dubljenjem kamena (ženinim popuštanjem, tj. pristajanjem na odnos).

Uočavam bitnu karakteristiku: „vodeni” izrazi nisu rezervirani za vokabular ribara, čak ni oni s direktnom poveznicom s ribarskim zanimanjem (pecanje, zabacivanje udice, nuđenje mamca i sl.). Protagonist/pošiljatelj

(Aristotel, Plutarh, Ovidije, Plinije Stariji itd.). Usporedi npr. podudaran primjer u Elijanovim Pismima seljaka 9.8.

17 Kao što je ranije rečeno, pošiljatelj pisama je sam autor, a primatelji većinom neimenovani, ali iz konteksta se može razaznati zanimanje pojedinih (npr. hetere ili muške prostitutke, a pismo 73 napisano je carici, Juliji Domni). 
pisma 1.7 jest ribar i stoga je njegovo slikovito izražavanje krajnje predvidljivo te usporedivo s izražavanjem Alkifronovih ribara, ali npr. protagonist iz 1.17 očito nije ribar, unatoč gomilanju vodenih izraza u njegovom opisu tehnike zavođenja (očito je riječ o konvencionaliziranim konceptualnim metaforama).

\section{Zaključak}

Analiza upotrebe konceptualnih metafora s izvornom domenom „voda” u Alkifronovoj, Filostratovoj i Aristenetovoj zbirci donijela je zanimljive, ali i donekle iznenađujuće rezultate. Sveukupno gledano, ovakvi izrazi relativno su nevažni unutar književne podvrste: u Alkifronovoj zbirci na njih otpada svega 4.5\% svih primjera, u Filostratovoj 5.5, a u Aristenetovoj nešto više, oko $7 \%$. Kudikamo zastupljenije su sfere sjedinjenja, nasilja i ratovanja, veselja, vatre i pogreške. ${ }^{18}$ Osim stilskih preferencija samih autora, objašnjenje leži i u određenim logičkim odrednicama. Naime, predigra i sam seksualni čin podrazumijevaju fizičke kontakte partnera (odatle brojnost primjera iz sfere sjedinjenja), a čin je uglavnom ugodna aktivnost (zato su česti primjeri iz sfere uzajamnog veselja i ugode). Nadalje, koncept grčke mitologije podrazumijeva zaljubljenost i strast kao posljedice djelovanja Erosa, ratobornog boga-streličara, stoga nas ne treba iznenaditi obilje primjera koji aludiraju na ranjavanje i nemoć „napadnutog” (o erotskoj metaforici nasilja i ratovanja detaljnije v. u Hajdarević 2017a).

Što se ostvarenih značenjskih kategorija tiče, u svim zbirkama vodenim izrazima moguće je aludiranje i na želju/zaljubljenost i na sam seksualni odnos. Pritom su primjeri u prve dvije zbirke otprilike podjednako raspoređeni, dok je u Aristenetovoj upotreba za aluzije na seksualni čin rijetka: pronađena su samo 3 primjera (naspram njih 10 za opis želje i/ili zaljubljenosti). Nadalje, jedino kod Aristeneta susrećemo i treću značenjsku kategoriju; opise zavođenja ili zavodljivosti (6 primjera).

Svim zbirkama zajednička je gotovo redovita poveznica „vodenih” erotskih izraza s atmosferom neugode i opasnosti po zaljubljenu osobu; prijeti joj utapanje ili brodolom. U Alkifronovoj i Filostratovoj zbirci baš sve na ovaj ili onaj način ljubavlju ugrožene i nemoćne zaljubljene osobe su

18 Omjer zastupljenosti sfera varira od autora do autora, ali sveukupna analiza svih kategorija prelazi okvire i zadani opseg ovoga rada. Za Alkifronovu zbirku detaljnije v. u Hajdarević 2017b. 
muškarci. U Aristenetovoj je situacija bitno drugačija te potencijalne žrtve mogu biti i žene $;^{19}$ u njegovoj zbirci žene češće pišu pisma nego u drugima, stoga je i češći prikaz njihove zaljubljenosti, želje i ljubavnih nevolja.

Alkifronove konzumativne erotske metafore, ostvarene kroz slike proždrljivih morskih čudovišta, redovito su povezane $\mathrm{s}$ heterama, dok $\mathrm{u}$ drugim zbirkama ovakva uvjetovanost nije pronađena. U Filostratovoj je pošiljatelj (autor) onaj koji „pije” (tj. seksualno konzumira) podjednako ljubavnike i ljubavnice, ponekad muške ili ženske prostitutke; time je Alkifronova tendencija ustvari izokrenuta. Aristenet pak konzumativne metafore za seksualni čin uopće ne koristi i u njegovoj zbirci nema žena-morskih čudovišta koja proždiru žrtve. Dio objašnjenja leži u činjenici da su njegove protagonistice rjeđe pripadnice heterskog zanata. ${ }^{20}$

Zanimljivo, ni u jednoj zbirci nije pronađen slikoviti izraz porijeklom iz ove sfere koji zaljubljenost, želju, zavođenje ili seksualni odnos prikazuje s pozitivnom intonacijom i bez upozorenja na potencijalno katastrofalan ishod. Čak i kad je seksualni (ili emocionalni) odnos ostvaren, izostaju izrazi poput npr. „uplovili su u zajedničku (bračnu) luku” ili „plovili su mirnim morem ljubavi", nema metaforičkih opisa bonace, a lađa nijednom nije alegorija stabilne veze. Očito, unutar podvrste naglasak je na nestabilnosti i opasnosti vodenih površina te biološkoj neprilagođenosti ljudskih bića ovoj životnoj sferi.

U Alkifronovoj zbirci uočena je snažna tendencija povezivanja „,vodenog” vokabulara u cjelini (pa tako i „vodenih” erotskih izraza) s pismima kojima su korespondenti ribari i članice njihovih obitelji. ${ }^{21}$ Slična uvjetovanost ne postoji u druge dvije zbirke. Dapače, gomilanje pomorske i ribolovne metaforike u Aristenetovom pismu 1.17 (u kojem akter nije ribar) kao da ima svrhu iznevjeriti očekivanje čitatelja i efektom očuđenja naglasiti autorovu inovativnost, koja je ranije uočena i na drugim formalnim i sadržajnim aspektima (usp. Hajdarević 2013).

19 U 2.16 ženu je „preplavila ljubav”, jedna zavedena žena je „upecana” u 1.5 3-5, tehnike zavođenja druge detaljno se opisuju ribolovnom terminologijom u 1.17, a na žene se odnose i seksualne aluzije u 1.7 i 1.17. Zanimljivo, u Aristenetovoj zbirci u 2.21.16-18 ženska privlačnost prikazana je ribarskom terminologijom, a muškarci su njezin potencijalni plijen; percepcija ribarenja kao muške aktivnosti u ovom je primjeru posve izokrenuta.

20 O učestalosti percepcije hetera kao gutačica muškaraca u grčkoj književnosti bilo je riječi ranije u radu (usp. npr. fusnotu 12 ).

21 Ukoliko particip glagola $\kappa \alpha \tau \alpha \pi i ́ v \omega$ u kontekstu 2.31.2.3-4 ne označava konzumaciju tekućine, baš svi Alkifronovi primjeri potječu iz Pisama ribara, tj. knjige 1. 
Dakle, komparacija zbirki iznjedrila je poneke zajedničke karakteristike: „vodena” metaforika koristi se relativno rijetko, a redovita je poveznica izraza ove vrste s potencijalnim opasnostima (tj. konceptualne metafore često imaju shemu: ljubav/zaljubljenost/seksualna želja je opasnost od utapanja/smetnja u plovidbi). S druge strane, uočene su i značajne razlike. Npr. Alkifronovi „vodeni” izrazi kontekstualno su uvjetovani (nalazimo ih u pismima ribara), a njegova konzumativna metaforika „rezervirana” je za opise veza s heterama (tipična shema: hetere su proždrljiva čudovišta). Nadalje, samo u Aristenetovoj zbirci uočen je povećan trud oko slikovitog opisa procesa zavođenja (npr. zavođenje je ribolov/plovidba u vjetar/ kapanje vode), ali i ventrilokvistički prikaz zaljubljenosti i želje „vodenom” metaforikom iz ženske perspektive.

Smatram da mi detaljnost provedenih analiza daje za pravo (pr)ocijeniti kvalitetu promatranog korpusa; zaključujem da su Aristenetovi „vodeni” erotski izrazi najmaštovitiji, načinom upotrebe najraznolikiji te stilski i književno najuspjeliji.

\section{Literatura}

Anderson, Graham (1986) Philostratus: Biography and Belles Lettres in the Third Century A.D., Croom Helm, Kent.

Anderson, Graham (1993) The Second Sophistic. A Cultural Phenomenon in the Roman Empire, Routledge, London/New York.

Arnott, William Geoffrey (1982) „Pastiche, Pleasantry, Prudish Eroticism: The Letters of Aristaenetus", YClS, 27, 291-320.

Bagić, Krešimir (2012) Rječnik stilskih figura, Školska knjiga, Zagreb.

Benner, Allen Rogers, Fobes, Francis Howard (1949) The Letters of Alciphron, Aelian and Philostratus, Harvard University Press, Cambridge.

Hajdarević, Sabira (2013) Umijeće varijacije u Aristenetovim Ljubavnim pismima, doktorska disertacija, Sveučilište u Zadru.

Hajdarević, Sabira (2015) „Grčke fikcionalne zbirke pisama u kontekstu; čimbenici razvoja i obilježja književne (pod)vrste”, Latina et Graeca, 26, 9-24.

Hajdarević, Sabira (2017a) „Ljubav i nasilje u Alkifronovim Pismima”, Sic: časopis za književnost, kulturu i književno prevođenje, 2, godina 7, tematski broj Anatomija ljubavi (The Anatomy of Love), online. 
Hajdarević, Sabira (2017b) „Alciphron’s Erotic Vocabulary Used as Evidence of (Dis)Unity of his Work", Systasis, 31, 1-20, online.

Hodkinson, Owen (2009) Brief Encounters: Studies in the Letters of Alciphron, Aelian, and Philostratus, doktorska disertacija, The Queen's College, Oxford University.

Hunter, Richard (2009) On Coming After: Studies in Post-Classical Greek Literature and Its Reception, Walter de Gruyter, Berlin.

Lausberg, Heinrich (1998) Handbook of Literary Rhetoric: A Foundation for Literary Study, Brill, Leiden.

Liddell, Henry George, Scott, Robert (1940) A Greek-English Lexicon. Revised and Augmented Throughout by Sir Henry Stuart Jones, with the Assistance of Roderick McKenzie, Clarendon Press, Oxford.

Mazal, Otto (1971) Aristaeneti Epistularum Libri II, Teubner, Stuttgart.

Rosenmeyer, Patricia (2001) Ancient Epistolary Fictions: The Letter in Greek Literature, Cambridge University Press, Cambridge.

Stanojević, Mateusz-Milan (2009) „Konceptualna metafora u kognitivnoj lingvistici: pregled pojmova", Suvremena lingvistika, 35, 68, 339-371.

Stanojević, Mateusz-Milan (2013) Konceptualna metafora: temeljni pojmovi, teorijski pristupi i metode, Srednja Europa, Zagreb.

Zanetto, Giuseppe (1987) „Un epistolographo al lavoro. Le lettere di Aristeneto", SIFC, 5, 193-211. 
SUMMARY

Sabira Hajdarević

"AQUATIC" EROTIC METAPHORS IN GREEK FICTIONAL EPISTOLARY COLLECTIONS

Alciphron's, Philostratus' and Aristaenetus' letter collections belong to Greek fictional epistolography, a subgenre that flourished from $2^{\text {nd }}$ century A.D. onwards. The authors chose erotica as a prevalent theme for their letters. However, the literary conventions of the subgenre forbid impropriety and drifts into pornography. So, the authors were entrapped between the obligation to be "decent" and the fact that their readers expected at least some nudity and sexual innuendos. Consequently, the stylistic devices used for erotic allusions had to be vivid and various in origin, and their expressive power became increasingly important in the collections of this subgenre.

Those erotic expressions are at the focus of this paper. In accordance with the need for brevity, only the ones that contain the idea of water, its consumption (or thirst), sailing or fishing are scrutinized. After the examples are detected, they are placed into a wider context: their importance and their meanings achieved in the "domicile" letters were determined (desire or being in love, seduction or the sexual act itself) and compared.

The final goal of the paper was to define the comprehensive role of the "aquatic" erotic expressions in the literary subgenre. The analysis revealed that the expressions of this kind were not used by the authors very often (their frequency in the collections is between 4.5 and 7 percent). Surprisingly, they are used in different ways (given that the collections share the same theme and the correspondents' occupations, the opposite result was expected) and Aristaenetus' are quite innovative and far more imaginative than the others'.

Keywords: Greek fictional epistolography; Alciphron; Philostratus; Aristaenetus; erotic metaphors; erotic expressions 